\title{
EVALUATION OF ADMINISTRATION OF Hibiscus rosa sinensis (HRS) LEAVES, POMEGRANATE (Punica granatum) PEELS (PP) EXTRACTS AND MIXTURE OF BOTH ON LIPID PROFILE OF ALBINO RATS
}

\author{
Mahmoud Sh.S. Elsayed* \\ Agric. Biochem. Dept., Fac. Agric., Ain Shams Univ., PO. Box 68, Hadayek, Shubra 11241, \\ Cairo, Egypt
}

Received: 25/07/2017 ; Accepted: 27/08/2017

\begin{abstract}
The possible lipid lowering properties of aqueous extracts of Hibiscus rosa sinensis leaves (AEHRS) and pomegranate (Punica granatum) peels (AEPP) were studied. Twelve groups of male albino rats, six rats each were used. The first group (I) was the normal control. The second group (II) was alloxanized diabetic control which showed a significant dyslipidemia as evidence by increasing in total serum cholesterol, triglycerides and decreased in HDL cholesterol level. Third (III), fourth (IV) and fifth (V) groups were given AEHRS with the dose level of 250,500 and $750 \mathrm{mg} / \mathrm{kg}$ body weight, respectively. Sixth (VI), seventh (VII) and eighth (VIII) groups were received AEPP extracts with the dose level of 100, 200 and $300 \mathrm{mg} / \mathrm{kg}$ body weight, respectively. Ninth (IX), tenth (X), eleventh (XI) groups were given mixture of AEHRS and AEPP with the dose level of 125/125, $225 / 225,350 / 350$ and one for diabetic rats which treated with a mixture of AEHRS leaves and AEPPtwelfth (XII)- at dose of $400 / 400 \mathrm{mg} / \mathrm{kg}$ body weight. All treated groups were given the extracts daily oral. Total serum cholesterol (TC), triglyceride (TG) and high density lipoprotein cholesterol (HDL-C) were determined after 7, 14 and 21 days. The results showed a decrease in serum cholesterol from $159.55 \pm 8.22$ to $136.64 \pm 9.07 \mathrm{mg} / \mathrm{dl}$, triglycerides levels from $141.00 \pm 4.6$ to $115.91 \pm 2.17 \mathrm{mg} / \mathrm{dl}$ and an increase of high density lipoprotein cholesterol level from $69.31 \pm 0.84$ to $111.31 \pm 1.13 \mathrm{mg} / \mathrm{dl}$ in groups administrated AEHRS leaves, AEPP and their mixture as compared with normal control and alloxanized diabetic control. The present results indicated that the aqueous extracts of (HRS leaves), (PP) and their mixture possess hypo-cholesterolemic and hypotriglyceridemic effects.
\end{abstract}

Key words: Hibiscus rosa sinensis, pomegranate (Punica granatum) peels, lipid profile, aqueous extract, hypolipidemic activity.

\section{INTRODUCTION}

Hibiscus rosa sinensis L. commonly referred to as Chinese Hibiscus, China rose or shoe flower (Jasvand) belongs to the family Malvacecae Kirtikar and Basu (1987). It is an ornamental plant widely grown in the tropical and subtropical regions of East Asia. Emilia coccinea is an annual widely distributed in tropical Asia and some part of Africa such as Ghana and Nigeria (Chillendon, 1956). The plant is edible, commonly used as salad in South East Asia and herbal medicine in South Eastern

\footnotetext{
* Corresponding author: Tel. : +205522610222 E-mail address:
}

Nigeria (Edeoga et al., 2005; Jimoh et al., 2010). The phytochemical compositions, pharmacological and therapeutic potentials of $H$. rosa-sinensis, E. coccinea, A. montanus and $A$. gangetica had previously been reported elsewhere Edeoga et al. (2005), Okoli et al. (2008), Bhaskar et al. (2011), Kensa (2011), Soni et al. (2011), Kumar et al. (2012) and Gopal et al. (2013). Ethanol/ water extracts of $H$. rosa sinensis, A. montanus, A. gangetica and $E$. coccinea exhibited varied hypolipidemic activities in rabbits placed on lipogenic diets in relation to the phytochemical peculiarities of the 
leaf extracts. The hypolipidemic property of $H$. rosa-sinensis, $A$. montanus, $A$. gangetica and $E$. coccinea is exemplified by the characteristics relative improvement in atherogenic index (AI) of treatment of hyperlipidemic rabbits (Hyl-Rs) treated with the four leaf extracts compared to the untreated group (Ojiako et al., 2013).

The protective roles of Hibiscus rosasinensis leaf, using various forms of the leaf products, against damages caused by hyperlipidemia induction in rats were established by Nwibo et al. (2016). The pharmacological and biological roles of the secondary metabolites of $H$. rosa-sinensis as hypoglycaemic and hypolipidemic agents are well established. Administration of the leaf products of HRS dose-dependently resulted in significant decreases $(\mathrm{P}<0.05)$ in the total cholesterol (TC) and low density lipoprotein cholesterol (LDL) levels while the high-density lipoprotein level was further increased.

Hibiscus rosa sinensis flower extract could play a hepatoprotecive role against hypercholesterolemia through the regulation of cholesterol levels (Biswas et al., 2014). Hypercholesterolaemic rats fed with Hibiscus rosa sinensis flower extracts in different doses for acute group animals showed a decrease in total cholesterol levels and a decrease of triglyceride and very low density lipoprotein cholesterol (VLDL) at the doses of $80 \mathrm{mg} / \mathrm{kg}$ BW. In the $160 \mathrm{mg} / \mathrm{kg} \mathrm{BW}$ induced a decrease in total cholesterol and triglyceride level and high significant decrease in VLDL level. 240 $\mathrm{mg} / \mathrm{kg} \mathrm{BW}$ showed significant decline in serum cholesterol, triglyceride and VLDL levels. A dose dependent reduction in atherogenic index was observed. The four plant extracts exhibited varied capacities to reduce the levels of serum total cholesterol (TC) after 14 days treatment of the various experimental groups, which was in the order: Hibiscus rosa sinensis $>$ Acanthus montanus $>$ Asystasia gangetica $>$ Emilia coccinea relative to untreated group. Also, rabbits treated with leaf extract of Hibiscus rosa-sinensis caused $60.64 \%$ reduction in serum low density lipoprotein cholesterol (LDL-C).

The phytosterols, specifically, $\beta$-sitosterol have been previously demonstrated to possessing blood cholesterol lowering activity by impeding intestinal cholesterol absorption routes and inhibitory action on hepatic cholesterol biosynthetic pathways (Ikeda and Sugano, 1983; Duester, 2001; Mayes and Botham, 2003). Expectedly, the intake of plant materials rich in $\beta$-sitosterol caused reduction in total serum cholesterol levels in the experimental animals (Weihrauch and Gardner, 1978; Moghadasian and Frohlich, 1999; AlDosari, 2011). Quantitative investigations had revealed the presence of substantial levels of $\beta$-sitosterol and related sterols in $H$. rosa sinensis (Chauhan and Kumari, 1984; Mishra et al., 2011), which could be adduced to be one amongst other factors responsible for its hypolipidemic attributes, demonstrated by comparable atherogenic index (AI) of hyperlipidemic rabbits (Hyl-Rs) treated with leaf extract of $H$. rosa sinensis with the normal/ control group. The effect of the oral administration of aqueous methanolic extract of Hibiscus rosa sinensis (HRS) leaves (400 $\mathrm{mg} / \mathrm{kg}$ ) on streptozotocin (STZ) induced diabetic rats and alternation in liver and kidney functions was investigated. The treatment of diabetic rats with hibiscus leaves extract, reduced level of plasma cholesterol (Zaki et al., 2017).

The pomegranate (Punica granatum L.) is an ancient fruit, it has been widely consumed in various cultures for thousands of years. The use of pomegranate fruit dates back to Biblical times and reports of its therapeutic qualities have echoed throughout the millennia (Longtin, 2003). The pomegranate belongs to family Punicaceae. It is native from the area of Iran to the Himalayas in northern India and has been cultivated and naturalized over the entire Mediterranean region since ancient times (Meerts et al., 2009). Actually, the pomegranate is widely cultivated throughout Iran, India, Mediterranean countries, the drier parts of Southeast Asia, tropical Africa, to some extent, in the United States, China, Japan, and Russia (Fadavi et al., 2006). The world pomegranate production amounts to approximately $1,500,000$ tons (FAOSTA-FAO, 2014). In Egypt, annual production of pomegranate is estimated at 64574 tons (Ismail et al., 2014). The peel amounts to approximately $60 \%$ of the pomegranate fruit weight as reported by Lansky and Newman (2007). The effect of pomegranate (Punica 
granatum L.) juice powders and peel powder extracts on the level of total cholesterol, low density lipoprotein cholesterol, high density lipoprotein cholesterol and triglycerides in rats serum as hypocholesterolemic agents was evaluated Abd El-Mageid et al. (2016).

The protective role of the fruit peel could be related to its flavonoid and polyphenolic contents, which possess antioxidative activity (Murthy et al., 2002). Moreover, the juice of Punica granatum is also known to prevent atherosclerosis, which further supports its antiatherogenic potential (Sestili et al., 2007). It is reported that addition of pomegranate juice to simvastatin in a macrophage cell culture model system improves the statin ability to inhibit cellular cholesterol biosynthesis and to protect the cells from oxidative stress. These effects could be related to the antioxidant hydrolysable tannin punicalagin and to the phytosterol $\beta$ sitosterol, which are both present in pomegranate (Rosenblat et al., 2013). Moreover, phytosterols of pomegranate consumption decreased serum cholesterol levels in dyslipidemic patients, as well as their cardiovascular risk (Moruisi et al., 2006; Rocha et al., 2011).

Pomegranate peel extract possesses antilipidemic activities in high lipid diet fed rats and that the pomegranate peel extract may be of use as antidyslipidemic agent. The decrease in the concentration of triglyceride, cholesterol, LDL cholesterol, VLDL cholesterol and increase in HDL cholesterol and hemoglobin content were observed in both normal and alloxan diabetic rats treated with crude powder of the peel of Punica granatum. The antidiabetic and hypolipidemic activity of the plant source is due to the phyto chemical constituents present in the peel of Punica granatum Radhika et al. (2011). Pomegranate peel powder (PPP) is capable to improve lipid profile and it is able reduce the probability of incidence of atherosclerosis in hypercholesterol rats (AlMuslehi, 2013).

It is concluded that the plant should be considered as an excellent candidate for future studies on dyslipidemia (Sadeghipour et al., 2014).
The aim of the present study was designed to evaluate the effect of aqueous extracts of pomegranate peels, Hibiscus rosa sinensis and their mixture on serum lipid profile in male albino rats.

\section{MATERIALS AND METHODS}

\section{Plant Material Collection}

The leaves of Hibiscus rosa sinensis were collected from Faculty of Agriculture, Ain Shams University garden while the fruits of pomegranate (Punica granatum) were purchased from local market. All plant materials were identified and authenticated by Horticulture Department, Faculty of Agriculture, Ain Shams University. The samples were washed with distilled water to remove any impurities and dried under shade. Then the dried plant materials were ground into powder with grinder mixture.

\section{Extract Preparation}

Boiled distilled water $(500 \mathrm{ml})$ was added to $8 \mathrm{~g}$ powder pomegranate peels and the same conditions with $8 \mathrm{~g}$ powder Hibiscus rosa sinensis, left them for 10 minutes and filtered. The filtrates were dried at $40-45^{\circ} \mathrm{C}$. The yields of powder residue were $5 \mathrm{~g}$ of punica granatum and $4 \mathrm{~g}$ of hibiscus rosa sinensis.

\section{Animals}

Male albino rats weighting $120 \pm 10 \mathrm{~g}$ were obtained from experimental farmland animals unit, Ministry of Health, Helwan, Cairo, Egypt. The animals were caged and provided with food and water ad-libitum. The rats were housed in cages with screen bottom in a controlled environment with $12 \mathrm{hr}$., light and $12 \mathrm{hr}$., dark cycles.Basal diet, vitamins and salt mixtures was done according to AOAC (2000). The rats were kept for one week to adapt to the laboratory conditions before starting of the experiment. Adult male albino rats (72 animals) were divided into twelve groups (6 rats/ each).

\section{Experimental Design}

The experimental groups were divided into the following groups.

Group I: normal control group. 
Group II: Alloxanized diabetic control group injected by $150 \mathrm{mg} / \mathrm{kg}$ bw (Pethe et al., 2016).

Group III: normal rats daily received AEHRS leaves of $250 \mathrm{mg} / \mathrm{kgbw}$.

Group IV: normal rats daily received AEHRS leaves of $500 \mathrm{mg} / \mathrm{kg}$ bw.

Group V: normal rats daily received AEHRS of $750 \mathrm{mg} / \mathrm{kg}$ bw.

Group VI: normal rats daily received AEPP of $100 \mathrm{mg} / \mathrm{kg}$ bw.

Group VII: normal rats daily received AEPP of $200 \mathrm{mg} / \mathrm{kg}$ bw.

Group VIII: normal rats daily received AEPP of $300 \mathrm{mg} / \mathrm{kg}$ bw.

Group IX: normal rats daily received AEHRS leaves and AEPP mixture of 125/125 $\mathrm{mg} / \mathrm{kg}$ bw.

Group X: normal rats daily received AEHRS leaves and AEPP mixture of 225/225 $\mathrm{mg} / \mathrm{kg}$ bw.

Group XI: normal rats daily received AEHRS leaves and AEPP mixture of 350/350 $\mathrm{mg} / \mathrm{kg}$ bw.

Group XII: diabetic rats daily received AEHRS leaves and AEPP mixture of 400/400 $\mathrm{mg} / \mathrm{kg}$ bw.

Duration of the experiment was extended for 21days.

\section{Collection of Blood}

The blood was withdrawn from the retroorbital sinus puncture of the eye using mild ether anesthesia. The collected samples at 7 days, 14 days and 21 days were centrifuged for $10 \mathrm{~min}$. according to Jadeja et al. (2009). Serum total cholesterol was measured according to the method of Allain et al. (1974), triglyceride was analyzed according to the method described by Fossati and Prencipe (1982) and HDLcholesterol was measured using the method of Lopes-Virella et al. (1977).

\section{Statistical Analysis}

All the data were expressed as mean $\pm \mathrm{SE}$. Statistical analysis was carried out using student's t-test to analyze the significance between the groups. A value of $\mathrm{P}<0.05$ was considered to be significant (Snedecor and Cochran, 1969).

\section{RESULTS AND DISCUSSION}

Estimation of lipid profile in all groups of rats were done at 7,14 and 21 days of the experimental period. Result of serum total cholesterol of rats administrated aqueous extract of Hibiscus rosa sinensis (AEHRS) leaves and aqueous extract of pomegranate (Punica granatum) peels (AEPP) were represented in Table 1 and Fig. 1 which obtained raising of total cholesterol in normal control, diabetic control as well as the last group (XII) which associated with time stage. The levels of total cholesterol were increased from $149.66 \mathrm{mg} / \mathrm{dl}$ to $154.35 \mathrm{mg} / \mathrm{dl}$ and 159.55 , from $190.99 \mathrm{mg} / \mathrm{dl}$ to $195.39 \mathrm{mg} / \mathrm{dl}$ and $199.38 \mathrm{mg} / \mathrm{dl}$ as well as from $160.31 \mathrm{mg} / \mathrm{dl}$ to $169.51 \mathrm{mg} / \mathrm{dl}$ and $173.90 \mathrm{mg} / \mathrm{dl}$ through 7, 14 and 21 days, respectively. On the other hand, aqueous extract of Hibiscus rosa sinensis (AEHRS) leaves treatments showed decreasing in total cholesterol after 7,14 and 21 days when compared to normal control, diabetic control and the last group (XII) in lower AEHRS leaves dose. Meanwhile medium and higher dose of AEHRS leaves resulted in remarkable decrease in total cholesterol after either 14 or 21 days of the experimental period. The total cholesterol levels were $144.86 \mathrm{mg} / \mathrm{dl}$, $142.33 \mathrm{mg} / \mathrm{dl}$ and $149.71,148.11$ in medium and high AEHRS leaves doses after 14 and 21 days, respectively compared with $154.35 \mathrm{mg} / \mathrm{dl}$ and $159.55 \mathrm{mg} / \mathrm{dl}, 195.39 \mathrm{mg} / \mathrm{dl}$ and $199.38 \mathrm{mg} / \mathrm{dl}$ as well as $169.51 \mathrm{mg} / \mathrm{dl}$ and $173.90 \mathrm{mg} / \mathrm{dl}$ in normal control group, diabetic control group and the last group (XII), respectively. These results indicated that AEHRS leaves works as lowering serum total cholesterol generally, but the lower dose induced its effect after 21 days while medium and higher dose appeared their effect after short time 7 and 14 days beside 21 days. These results are in agreement with those of Pethe et al. (2016). Regarding to aqueous extract treatment of pomegranate (Punica granatum) peels (AEPP) it showed significant decrease in total cholesterol directly after 14 and 21 days of the experimental period with the lower and medium 
Table 1. Influence of different concentrations of natural products (aqueous extract of Hibiscus rosa sinensis (AEHRS) leaves, aqueous extract of pomegranate (Punica granatum) peels (AEPP) and their mixture) on serum total cholesterol (mg/dl) in male albino rats

\begin{tabular}{|c|c|c|c|c|c|c|c|c|c|c|c|c|}
\hline \multirow{2}{*}{$\begin{array}{c}\text { Treatment } \\
\text { (Day) }\end{array}$} & \multirow{2}{*}{$\begin{array}{l}\text { Normal } \\
\text { control }\end{array}$} & \multirow{2}{*}{$\begin{array}{c}\text { Diabetic } \\
\text { control }\end{array}$} & \multicolumn{3}{|c|}{ AEHRS leaves (mg/kg bw) } & \multicolumn{3}{|c|}{$\operatorname{AEPP}(\mathrm{mg} / \mathrm{kg} \mathrm{bw})$} & \multicolumn{4}{|c|}{ AEHRS leaves + AEPP mixture (mg/kg bw) } \\
\hline & & & 250 & 500 & 750 & 100 & 200 & 300 & $125 / 125$ & $225 / 225$ & $350 / 350$ & $\begin{array}{c}\text { Diabetic rats + } \\
400 / 400\end{array}$ \\
\hline 14 & $154.35 \pm 4.66$ & $195.39 \pm 5.75$ & $147.50 \pm 7.50$ & $144.86 \pm 7.03 *$ & $142.33 \pm 8.01 *$ & $144.44 \pm 5.37 *$ & $143.25 \pm 7.72 *$ & $150.41 \pm 10.5$ & $138.0 \pm 8.77$ & $135.44 \pm 7.73$ & $133.86 \pm 11.3$ & $169.51 \pm 9.01$ \\
\hline 21 & $159.55 \pm 8.22$ & $199.38 \pm 4.77$ & $149.11 \pm 6.00$ & $149.71 \pm 8.6^{*}$ & $148.11 \pm 9.7^{*}$ & $149.40 \pm 6.82 *$ & $150.98 \pm 4.70^{*}$ & $155.07 \pm 9.51$ & $142.33 \pm 6.75^{*}$ & $139.44 \pm 8.66^{*}$ & $136.64 \pm 9.07 *$ & $173.90 \pm 7.99$ \\
\hline
\end{tabular}

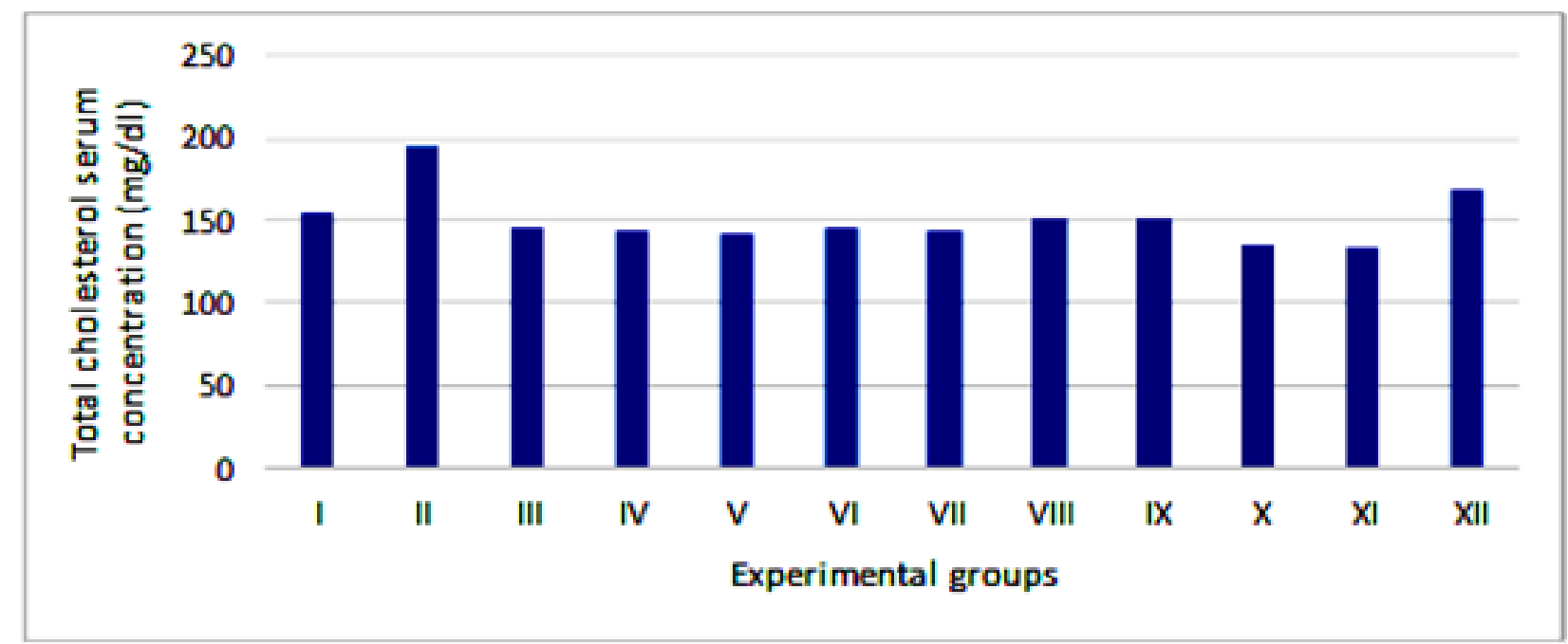

Fig. 1. Influence of different concentrations of natural products (aqueous extract of Hibiscus rosa sinensis (AEHRS) leaves, aqueous extract of pomegranate (Punica granatum) peels (AEPP) and their mixture) on serum total cholesterol (mg/dl) in male albino rats 
doses of AEPP comparing to I, II and XII groups. These results are in agreement with Gosain et al. (2010) who suggested that the higher dose of AEPP had no significant effect in decreasing serum total cholesterol after either 14 or 21 days in the present study. These mean that the medium dose of AEPP was recommended to reduce serum total cholesterol than higher dose. Respecting to mixture of natural product of AEHRS leaves and AEPP, results represented in Table 1 cleared that natural product mixture resulted in significant decrease after period 21 days in all mixture groups when compared to normal control, diabetic control and the last group (XII) not only that but also the lowering in these groups was markedly recorded in $225 / 225 \mathrm{mg} / \mathrm{kg}$ bw and $350 / 350 \mathrm{mg} / \mathrm{kg}$ bw doses of mixture groups whereas the values were $139.44 \mathrm{mg} / \mathrm{kg}$ and $136.64 \mathrm{mg} / \mathrm{dl}$, respectively comparing with $199.38,173.90$ and 159.55 $\mathrm{mg} / \mathrm{dl}$ in diabetic control, the last group (XII) and normal control group, respectively. Higher dose $(350 / 350 \mathrm{mg} / \mathrm{kg}$ bw, XI group) of natural products mixture resulted in lowering serum total cholesterol approximately similar to individual dose after 7 days. In conclusion, mixture natural products used in the study were more effective in lowering serum total cholesterol compared with (I, II and XII) groups.

Table 2 and Fig. 2 represents the results of serum high density lipoprotein cholesterol (HDLcholesterol) in the experimental rats. Results revealed that HDL-cholesterol was slightly increase in normal control, diabetic control rats and group XII through the experimental time especially at 21 days from $60.33 \mathrm{mg} / \mathrm{dl}$ and $65.90 \mathrm{mg} / \mathrm{dl}$ after 7 and 14 days to $69.31 \mathrm{mg} / \mathrm{dl}$ after 21 days, from $42.11 \mathrm{mg} / \mathrm{dl}$ and $45.31 \mathrm{mg} / \mathrm{dl}$ after 7 and 14 days to $49.35 \mathrm{mg} / \mathrm{dl}$ after 21 days as well as from $59.31 \mathrm{mg} / \mathrm{dl}$ and $60.00 \mathrm{mg} / \mathrm{dl}$ after 7 and 14 days to $63.51 \mathrm{mg} / \mathrm{dl}$ after 21 days, respectively. However, AEHRS leaves revealed marked increase in HDL-cholesterol after all experimental periods especially after at 21 days compared with normal control, diabetic control groups and group XII in all experimental doses as shown in Table 2. Although, there is an increase in HDL-cholesterol but this increase was dose-dependent, that relation was not right after 7 days whereas still right after 14 and 21 days at low ,medium and high doses. Looking for HDL-cholesterol after 7 days the values were $61.77 \mathrm{mg} / \mathrm{dl}, 72.55 \mathrm{mg} / \mathrm{dl}$ and $69.37 \mathrm{mg} / \mathrm{dl}$ at the first, second and third dose of AEHRS leaves compared with $60.33 \mathrm{mg} / \mathrm{dl}, 42.11 \mathrm{mg} / \mathrm{dl}$ and $59.31 \mathrm{mg} / \mathrm{dl}$, in normal control, diabetic control and the last group XII .These results are in accordance with Sikarwar and Patil (2015) who found that AEHRS flowers ethanolic extract fraction $(500 \mathrm{mg} / \mathrm{kg}$ body weight) significantly increased HDL levels as compared to control. This outcome may due to the better activity of lecithin, cholesterol acetyltransferase, which combines free cholesterol, free LDL into HDL. On the other hand, AEPP caused increase in HDL-cholesterol compared with I,II and XII groups but this raise was slightly increase as shown in AEHRS leaves. Regarding to, combined groups which received natural products mixture, highly significant increase was observed in all groups and at all period especially at 21 days comparing with normal control, diabetic control and the last group XII. At this point it is noticed that all combination of natural products raised HDL-cholesterol and the mixture of AEHRS leaves and AEPP was more better in elevating HDL-cholesterol than all of them individually. Significant lowering of total cholesterol and raise in HDL-cholesterol is a very desirable biochemicals state for preventation of atherosclerosis and ischaemic conditions. AEHRS leaves and AEPP prove to have a hypolipidemic potential due to the presence of flavonoids, alkaloids, glycosides phenols, tannin and saponins in whole plant of Hibiscus rosa sinensis and pomegranate. Notably, these phyto-chemicals have been proposed to possessing blood cholesterol level lowering effect and might be useful in the treatment of cardiovascular diseases caused by hyperlipidemia.

Table 3 and Fig. 3 represents the results of serum triglycerides in the experimental rats. Results revealed that, triglycerides were slight increased in normal control, diabetic control and the last group XII rats through the experimental time especially, at 21 days which slightly increased from $130.66 \mathrm{mg} / \mathrm{dl}$ and $139.11 \mathrm{mg} / \mathrm{dl}$ after 7,14 days to $141.00 \mathrm{mg} / \mathrm{dl}$ after 21 days and from $195.49 \mathrm{mg} / \mathrm{dl}$ and $199.31 \mathrm{mg} / \mathrm{dl}$ after 7 , 14 days which reach to $202.35 \mathrm{mg} / \mathrm{dl}$ after 21 days and raised from $132.11 \mathrm{mg} / \mathrm{dl}$ and 143.91 
Table 2. Influence of different concentrations of natural products (aqueous extract of Hibiscus rosa sinensis (AEHRS) leaves, aqueous extract of pomegranate (Punica granatum) peels (AEPP) and their mixture) on serum HDL-cholesterol $\mathrm{mg} / \mathrm{dl}$ in male albino rats

\begin{tabular}{|c|c|c|c|c|c|c|c|c|c|c|c|c|}
\hline \multirow{2}{*}{$\begin{array}{c}\text { Treatment } \\
\text { (Day) }\end{array}$} & \multirow{2}{*}{$\begin{array}{l}\text { Normal } \\
\text { control }\end{array}$} & \multirow{2}{*}{$\begin{array}{l}\text { Diabetic } \\
\text { control }\end{array}$} & \multicolumn{3}{|c|}{ AEHRS leaves (mg/kg bw) } & \multicolumn{3}{|c|}{ AEPP (mg/kg bw) } & \multicolumn{4}{|c|}{ AEHRS leaves+ AEPP mixture (mg/kg bw) } \\
\hline & & & 250 & 500 & 750 & 100 & 200 & 300 & $125 / 125$ & $225 / 225$ & $350 / 350$ & $\begin{array}{c}\text { Diabetic rats + } \\
400 / 400\end{array}$ \\
\hline 7 & $60.33 \pm 0.17$ & $42.11 \pm 0.59$ & $61.77 \pm 0.31$ & $72.55 \pm 0.75$ & $69.37 \pm 0.93$ & $62.66 \pm 0.88$ & $71.84 \pm 0.95$ & $69.51 \pm 0.11$ & $81.33 \pm 0.99$ & $68.88 \pm 0.66$ & $100.88 \pm 0.90^{*}$ & $59.31 \pm 0.77$ \\
\hline 14 & $65.90 \pm 0.11$ & $45.31 \pm 0.71$ & $73.73 \pm 0.76$ & $75.34 \pm 0.66$ & $80.21 \pm 0.50$ & $74.02 \pm 0.73$ & $74.01 \pm 0.55$ & $79.73 \pm 0.36$ & $99.77 \pm 0.7 *$ & $107.31 \pm 0.77 *$ & $108.88 \pm 0.29 *$ & $60.00 \pm 0.78$ \\
\hline 21 & $69.31 \pm 0.84$ & $49.35 \pm 0.55$ & $79.11 \pm 0.80^{*}$ & $80.55 \pm 0.55^{*}$ & $85.03 \pm 0.35^{*}$ & $81.66 \pm 0.47$ & $75.11 \pm 0.96$ & $90.88 \pm 0.55$ & $102.71 \pm 0.37 *$ & $111.31 \pm 1.13 *$ & $110.71 \pm 0.12 *$ & $63.51 \pm 0.34$ \\
\hline
\end{tabular}

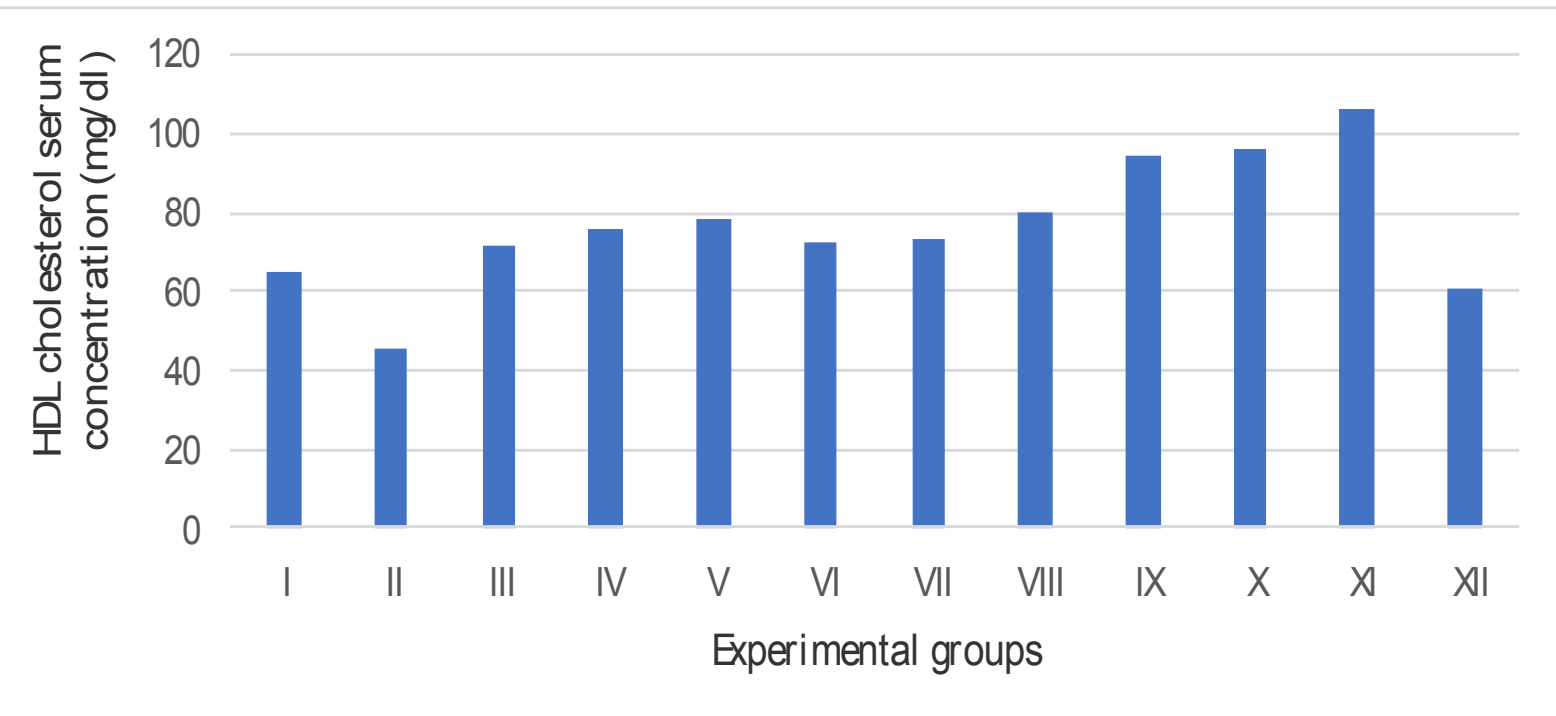

Fig. 2. Influence of different concentrations of natural products (aqueous extract of Hibiscus rosa sinensis (AEHRS) leaves, aqueous extract of pomegranate (Punica granatum) peels (AEPP) and their mixture) on serum HDL-cholesterol $\mathrm{mg} / \mathrm{dl}$ in male albino rats 
Table 3. Influence of different concentrations of natural products (aqueous extract of Hibiscus rosa sinensis (AEHRS) leaves, aqueous extract of pomegranate (Punica granatum) peels (AEPP) and their mixture) on serum triglycerides $\mathrm{mg} / \mathrm{dl}$ in male albino rats

\begin{tabular}{|c|c|c|c|c|c|c|c|c|c|c|c|c|}
\hline \multirow{2}{*}{$\begin{array}{c}\text { Treatment } \\
\text { (Day) }\end{array}$} & \multirow{2}{*}{$\begin{array}{l}\text { Normal } \\
\text { control }\end{array}$} & \multirow{2}{*}{$\begin{array}{c}\text { Diabetic } \\
\text { control }\end{array}$} & \multicolumn{3}{|c|}{ AEHRS leaves (mg/kg bw) } & \multicolumn{3}{|c|}{$\operatorname{AEPP}(\mathrm{mg} / \mathrm{kg}$ bw) } & \multicolumn{4}{|c|}{ AEHRS leaves + AEPP mixture (mg/kg bw) } \\
\hline & & & 250 & 500 & 750 & 100 & 200 & 300 & $125 / 125$ & $225 / 225$ & $350 / 350$ & $\begin{array}{c}\text { Diabetic rats }+ \\
400 / 400\end{array}$ \\
\hline 7 & $130.66 \pm 3.7$ & $195.49 \pm 2.01$ & $120.33 \pm 3.37$ & $121.54 \pm 3.31$ & $123.31 \pm 5.11$ & $125.51 \pm 2.61$ & $124.71 \pm 4.15$ & $125.71 \pm 5.31$ & $112.33 \pm 3.75^{*}$ & $110.34 \pm 5.90^{*}$ & $105.33 \pm 2.13$ & $132.11 \pm 3.70$ \\
\hline 14 & $139.11 \pm 2.08$ & $199.31 \pm 3.51$ & $125.01 \pm 4.31$ & $131.71 \pm 3.36$ & $125.66 \pm 3.31$ & $131.13 \pm 2.11$ & $131.11 \pm 3.6$ & $130.18 \pm 2.91$ & $118.34 \pm 2.88 *$ & $115.5 \pm 5.78^{*}$ & $111.1 \pm 3.13 *$ & $143.91 \pm 2.09$ \\
\hline 21 & $141.00 \pm 4.6$ & $202.35 \pm 4.5$ & $135.60 \pm 5.33$ & $136.83 \pm 2.71$ & $133.11 \pm 4.11$ & $134.31 \pm 4.7$ & $138.61 \pm 4.66$ & $137.77 \pm 4.4$ & $120.78 \pm 3.28 *$ & $120.88 \pm 2.88^{*}$ & $115.91 \pm 2.17$ & $145.81 \pm 3.33$ \\
\hline
\end{tabular}

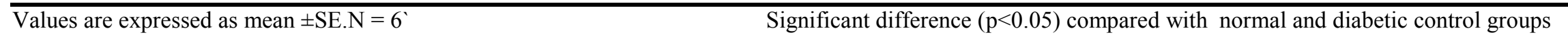

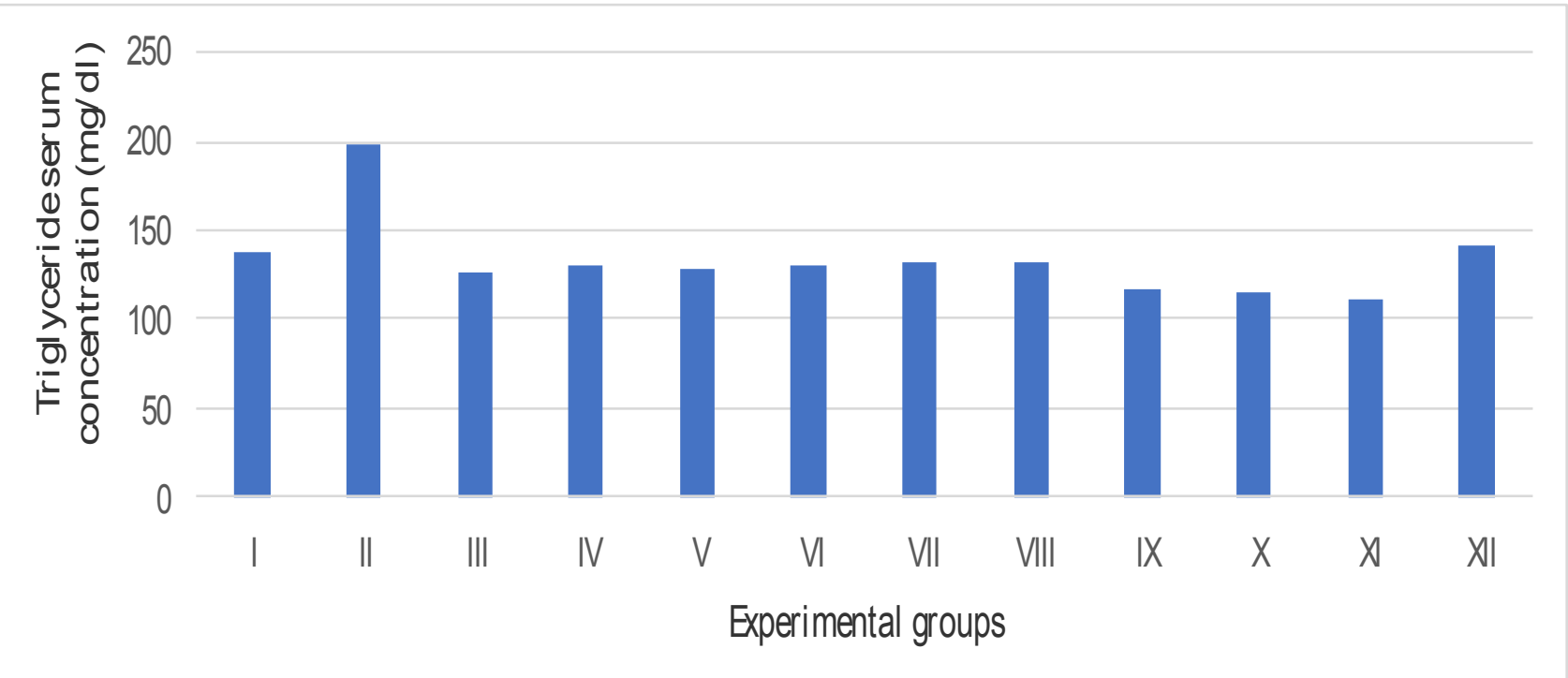

Table 3. Influence of different concentrations of natural products (aqueous extract of Hibiscus rosa sinensis (AEHRS) leaves, aqueous extract of pomegranate (Punica granatum) peels (AEPP) and their) mixture on serum triglycerides mg/dl in male albino rats 
$\mathrm{mg} / \mathrm{dl}$ after 7 and 14 days to $145.81 \mathrm{mg} / \mathrm{dl}$ after 21 days, respectively. However, oral treatment with AEHRS leaves revealed marked decrease in triglycerides after all experimental periods compared with normal control, diabetic control and the last group XII as shown in Table 3. Meanwhile, the low and medium doses of AEHRS leaves induced lowering of this value which was $120.33 \mathrm{mg} / \mathrm{dl}$ and $121.54 \mathrm{mg} / \mathrm{dl}$ compared with normal control $(130.66 \mathrm{mg} / \mathrm{dl})$ diabetic control $(195.49 \mathrm{mg} / \mathrm{dl})$ and the last group XII $(132.11 \mathrm{mg} / \mathrm{dl})$ after7 days. On the other hand, oral treatment with AEPP decreased triglycerides compared with normal control, diabetic control and the last group XII, but this decrease was not lower as shown in AEHRS treatment. Regarding to combined group which received natural products mixture, highly significant decrease was observed in all groups and at all experimental period when comparing with normal control,diabetic control and the last group XII.At this point it is noticed that all combination of natural products, decreased serum triglycerides and this decreasing dependent on dose. All mixture doses decreased triglycerides as shown in Table 3 compared with normal control, diabetic control and the last group XII. In addition, data in Table 3 cleared that the increasing in triglycerides values was associated with increasing in time period. These data are in agreement with Pethe et al. (2016) who reported that root extracts of Hibiscus rosa sinensis have been found to possess hypolipidemic activity, which was observed in dose dependent manner as evidence by reduction in the level of total cholesterol, triglycerides, VLDL, LDL and increases in HDL levels significantly. The most common lipid abnormalities in diabetes are hypertriglyceridemia and hyper-cholesterolemia. It is well established fact that increase level of triglyceride is a risk factor for atherosclerotic coronary diseases. Repeated administration of root extract of Hibiscus rosa sinensis for 28 days, significantly improved hypertriglyceridemia and hypercholesterolemia, bringing their levels in groups $(100 \mathrm{mg} / \mathrm{kg}$ and $200 \mathrm{mg} / \mathrm{kg} \mathrm{bw})$ to that of the control group. The hypolipidemic effect of AEHRS leaves and AEPP may be due to the synergyistic action of its different constituents, including soluble fiber, sterols, flavonoids and high content of polyunsaturated fatty acids. However, it had been hypothesized that AEHRS and AEPP producing anti-hyperlipidemic effect by decreasing cholesterol synthesis, and more importantly by having antioxidant properties. The decreasing in the concentration of triglyceride, cholesterol, LDL cholesterol, VLDL cholesterol, and increase in HDLcholesterol were observed in normal rats treated with crude powder of the peel of Punica granatum. The hypolipidemic activity of the plant source is due to the phytochemical constituents present in the peel of Punica granatum (Radhika et al., 2011).

\section{Conclusion}

It had been concluded that Hibiscus rosa sinensis aqueous leaves extract and pomegranate (Punica granatum) aqueous peels extract have anti-hypercholesterolemia activity and antihypertriglyceridemia activity. Also, these findings observe that AEHRS and AEPP elevated serum HDL-cholesterol level.

\section{REFERENCES}

AOAC (2000). Official Methods of Analysis of Association of Official Agriculture chemists, Washington DC.

Abd El-Mageid, M.M., A.R. Salama, M.A.M. Saleh and H.N. Abo-Taleb (2016). Evaluation of antidiabetic, hypocholesterolemic of pomegranate (Punica granatum L.) juice powders and peel powder extracts in male albino rats. IOSR J. Pharm. Biol. Sci., 11: 53-64.

Al-Dosari, M.S. (2011). Hypolipdemic and antioxidant activities of avocado fruit pulp on high cholesterol fed diet in rats. Afr. J. Pharm. Pharmacol., 5(12): 1475-1483.

Allain, C.C., L.S. Poon, C.S. Chan, W. Ricmmond and P.C. Fu (1974). Enzymatic determination of total serum cholesterol. Clin. Chem., 20 : 470-475.

Al-Muslehi, M.S. (2013). Effect of powder of pomegranate (Punica granatum) peels on lipid profile in Hypercholesterolmic rats. Kufa J. Veter. Med. Sci., 4 (1) :111-117. 
Bhaskar, A., V. Ithya and V.G. Vidhya (2011). Phytochemical screening and in vitro antioxidant activities of the ethanolic extract of Hibiscus rosa sinensis L. Ann. Biol. Res., 2 (5): 653-661.

Biswas, A., U.J.A.D. Souza, S. Bhat and D. Damodar (2014). The hepatoprotective effect of Hibiscus rosa sinensis flower extract on diet induced hypercholesterolemia in male albino rats., J. Med. Pharm. Sci., 4 (6): 1-10.

Chauhan, A. and U. Kumari (1984). Sterols of some malvaceous plants with particular emphasis on cholesterol occurrence. Biol. Sci., 54 (3): 236-239.

Chillendon, F. (1956). Dictionary of Plant Plus Supplements. Oxford Univ. Press, 113-115.

Duester, K.C. (2001). Avocado fruit is a rich source of beta-sitosterol. J. Ame. Diet. Assoc., 101: 404-405.

Edeoga, H.O., D.E. Okwu and B.O. Mbaebia (2005). Phytochemical constituents of some Nigerian medicinal plants. Afr. J. Biotechnol., 4 (7): 685-688

Fadavi, A., M. Barzegar and H.M. Azizi (2006). Determination of fatty acid and total lipid content in oil seed of 25 pomegranate varieties grown in Iran. J. Food Comp. Anal., 19: 676-680.

FAOSTAT-FAO (2014). Statistical database. Food and Agriculture Organization of the United Nations, Codex, Alimentarius Commision. http://www.fao.org.

Fossati, P and L. Prencipe (1982). Serum triglycerides determined colorimetrically with an enzyme that produces hydrogen peroxide. Clin. Chem., 28: 2077-80.

Gopal, T.K., G. Megha, D. Chamundeeswari and C.U. Reddy (2013). Phytochemical and pharmacological studies on whole plant of Asystasia gangetic. Indian J. Res. Pharm. Biotechnol., 1(13): 365-370.

Gosain, S., R. Irechiaya and P.C. Sharma (2010). Hypolipidemic effect of ethanol extract from some leaves of Hibiscus salbdarifla L. in hyperlipidemic rats. Acta. Pol. Pharm., 67 (2): 179-184.
Ikeda, I. and M. Sugano (1983). Some aspects of mechanism of inhibition of cholesterol absorption by beta-sitosterol. Biochem. Biophys. Acta, 732: 651-658.

Ismail, O.M., R.A.A. Younis and A.M. Ibrahim (2014). Morphological and molecular evaluation of some Egyptian pomegranate cultivars. Afr. J. Biotechnol., 13(2): 226-237.

Jadeja, R.N., M.G. Thounaojum, V. Patel, R.V. Devker and A.V. Ramachandran (2009). Antihyperlipidemic potential of a polyherbal preparation on triton WR 1339 (Tylox apol) induced hyperlipidemia A. Comparison with lovastation. Int. J. Green Pharm, 3 supp. 2: 119-124.

Jimoh, F.O., A.A. Adedapo, A.A. Aliero, S. Koduru and A.J. Afolayan (2010). Evaluation of the polyphenolic, nutritive and biological activities of the acetone, methanol and water extracts of Amaranthus asper. Open Complement. Med. J., 2: 7-14.

Kensa, V.M. (2011). Studies on phytochemical profile and antimicrobial activity on Asystasia gangetica (L.) T. Anderson. Plant Sc. Feed, 1 (7): 112-117.

Kirtikar, R. and B.D. Basu (1987). Indian Medicinal Plants. $2^{\text {nd }}$ ed. Dehra Dun: International Book Distributors, 2078-2079.

Kumar, L., G. Chakraborthy, V. Singh and A. Mazumder (2012). Hibiscus rosa sinensis: A review on divine herb. J. Adv. Pharm. Healthcare Res., 2(4): 9-18.

Lansky, E.P. and R.A. Newman (2007). Punica granatum (pomegranate) and its potential for prevention and treatment of inflammation and cancer. J. Ethnopharmacol, 109(2): 177206.

Longtin, R. (2003). The pomegranate: nature's power fruit?. J. Natl. Cancer Inst., 95:346348.

Lopes-Virella, M.F., P. Stone, S. Ellis and J.A. Colwell (1977). Cholesterol determination in high-density lipoproteins separated by three different methods. Clin. Chem., 23: 882-884.

Mayes, P.A. and K.M. Botham (2003). Lipid transport and storage. In: Murray R.K.; Granner, D.K.; Mayes, P.A. and Rodwell, 
VW (Ed.). Harper's Illustrated Biochem. $26^{\text {th }}$ Ed. Calif., Lange Med. Books/McGraw-Hill.

Meerts, I.A.T.M., C.M. Verspeek-Rip, C.A.F. Buskens, H.G. Keizer, J. Bassaganya-Riera, Z.E. Jouni, A.H.B. Van Huygevoort, F.M. Van-Otterdijk and E.J. Van de Waart, (2009). Toxicological evaluation of pomegranate seed oil. Food Chem. Toxicol., 47 (6): 1085-1092.

Mishra, R., S.M. Karmarkar and A.M. Bhagwat (2011). Preliminary dose dependent study on anti-hyperlipidemic activity of Hibiscus rosa sinensis Linn leaves on triton WR 1339 induced hyperlipidemic mice model. Asian. J. Pharm. Clin. Res., 4(2): 100-102.

Moghadasian, M.H. and J.J. Frohlich (1999). Effects of dietary phytosterols on cholesterol metabolism and atherosclerosis: Clinical and experimental evidence. Ame. J. Med., 107: 588-594.

Moruisi, K.G., W. Oosthusizen and A.M. Opperman (2006). Phytosterols/stanols lower cholesterol concentrations in familial hypercholesterolemia subjects: a systemic review with metaanalysis. J. Ame. Coll. Nut., 25 (1): 41-48.

Murthy, K.N.C., G.K. Jayaprakasha and R.P. Singh (2002). Studies on antioxidant activity of pomegranate (Punica granatum) peel extract using in vivo models. J. Agric. Food Chem., 50 (17): 4791-4795.

Nwibo, D.D., M.I. Eze and I.M. Okonkwo (2016). Effect of Hibiscus rosa-sinensis leaf products on haematological indices, lipid profile and hepatic parameters of hyperlipiemic rats, Afr. J. Pharm. Pharmacol, 10 (12): 223-229.

Ojiako, A., P.C. Chikezie and U.C. Zedech (2013). Serum lipid profile of hyperlipidemic rabbits (Lepustown sendii) treated with leaf extracts of Hibiscus rosa-sinensis, Emilia coccinea, Acanthus montanus and Asystas gangetica. J. Med. Pl. Res., 7 (43): 32263231 .

Okoli, C.O., P.A. Akah, N.J. Onuoha, T.C. Okoye, A.C. Nwoye and C.S. Nworu (2008). An experimental evaluation of the antimicrobial, anti-inflammatory and immunological properties of a traditional remedy for furuncles. BMC Compl. Altern. Med., 8: 27.

Pethe, M., R.K. Gupta, M. Smita and G. Vijay (2016). Assessment of various biological activities of Hibiscus rosa sinensis root extract in alloxan induced diabetic rats. Int. J. Biomed. Res., 7(12): 865-871.

Radhika, S., K.H. Smila and R. Muthezhilan (2011). Anti-diabetic and hypolipidimic activity of Punica granatum Linn on Alloxan induced rats. World J. Med. Sci., 6 (4): 178182.

Rocha, M., C. Banuls, L. Bellod, A. Jover, V.M. Victor and A. Hernandez-Mijares (2011). A review on the role of phytosterols: new insights into cardiovascular risk. Current Pharmaceutical Design, 17(36): 4601-4075.

Rosenblat, M., N. Volkova and M. Aviram (2013). Pomegranate phytosterol ( $\beta$-sitosterol) and polyphenolic antioxidant (Punicalagin) addition to stating, significantly protected against macrophage foam cells formation. Atherosclerosis, 226(1): 110-117.

Sadeghipour, A., M. Eidi, A.L. Kavagani, R. Ghahramani, S. Shahbzadeh and A. Anissian (2014). Lipid lowering effect of Punica granatum L. Peel in high lipids diet fed male rats. Evidence-Based Complementary and Alternative Med., 1-5.

Snedecor, G.W. and W.C. Cochran (1969). In: Statistical Methods". $6^{\text {th }}$ Ed. Iowa State Univ., Press Anes, Iowa, USA.

Sestili, P., C. Martinelli and D. Ricci (2007). Cytoprotective effect of preparations from various parts of Punica granatum L. fruits in oxidatively injured mammalian cells in comparison with their antioxidant capacity in cell free systems. Pharmacol. Res., 56 (1): 18-26.

Sikarwar, M.S. and M.B. Patil (2015). Antihyperlipidemic activity of Hibiscus rosa sinensis Linn. Ethanolic extract fractions. Int. J. Health Appl. Sci., 4 (2): 73-78.

Soni, D., A. Gupta, R. Solanki and G.K. Jana (2011). Pharmacognostical, phytochemical and physiochemical findings over the root extract of Hibscus rosa sinesis (Malvacae). J. Nat. Prod. Plant Res., 1(4): 73-79. 
Weihraucn, J.L. and J.M. Gardner (1978). Sterol content of foods of plant origin. J. Ame. Diet. Assoc., 73: 39-47.

Zaki, L.H., S.M. Mohamed, S.A.E. Bashandy, F.A. Morsy, K.M Tawfic and A.A. Shahat
(2017). Hypoglycemic and antioxidant effects of Hibiscus rosa sinensis (HRS) L. leaves extract on liver and kidney damage in streptozotocin induced diabetic rats, Afr. J. Pharm. Pharmacol., 11 (13): 161-169.

\section{تقييم إضافة مستخلصات أوراق نبات الهيبسكس روزا سبنتسس وقشور الرمان وخليط منهما معا على ليبيدات الام فى الجرذان البيضاء \\ محمود شكري صادق السيد}

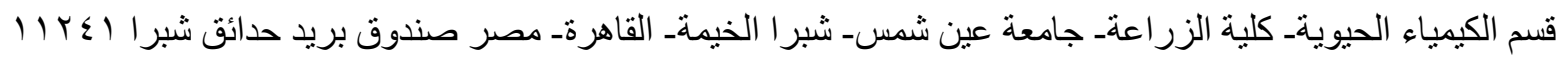

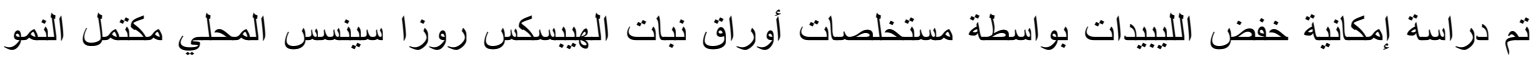

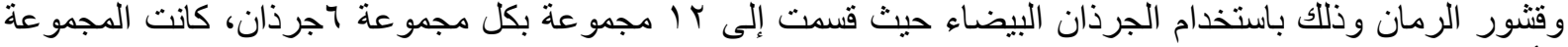

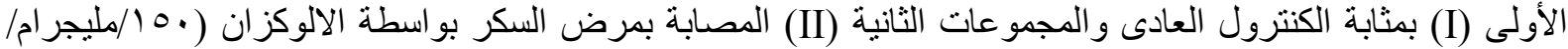

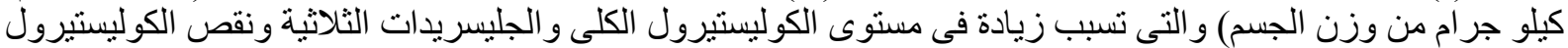

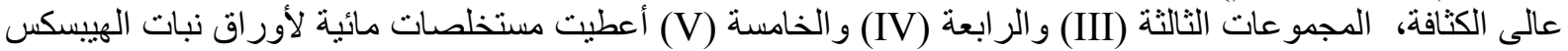

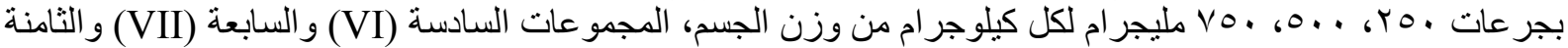

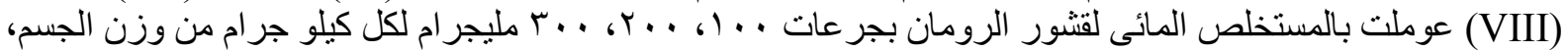

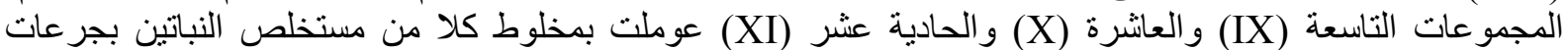

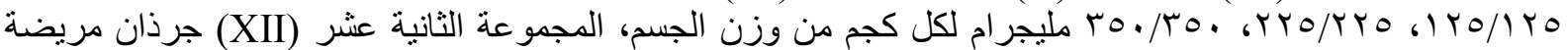

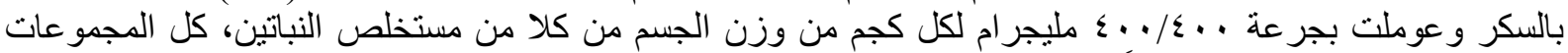

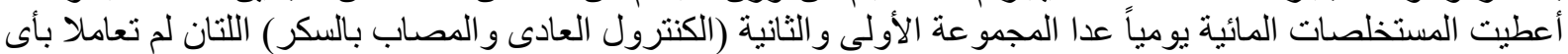

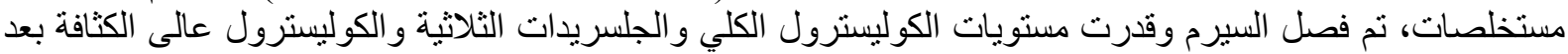

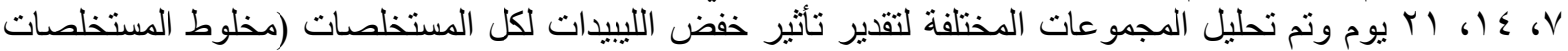
وكل مستخلص على حدة) وقد وجد انخفاض في مستوى الكوليسترول الكلى و الجلسريدات الثلاثية وزيادة الكوليسترول

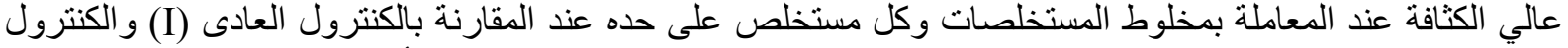

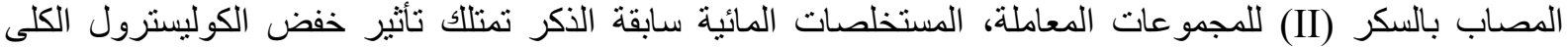

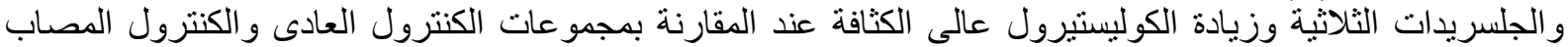
بالسكر.

أستاذ الكيمياء الحيوية ـ كلية الزر اعة - جامعة القاهرة.

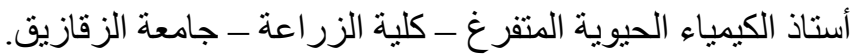

